\title{
SHARIA ECONOMIC EMPOWERMENT EFFORTS THROUGH KOPERASI WANITA SRIKANDI, KELURAHAN SIDOKERTO, KECAMATAN BUDURAN, SIDOARJO
}

\author{
Hersa Farida Qoriani \\ hersafa@gmail.com
}

\begin{abstract}
The purpose of this research is to analyze the role of Koperasi wanita in efforts to empower women and empower the Islamic economy (especially mothers around the Koperasi wanita, Sidokerto, Kecamatan Buduran, Sidoarjo), the welfare conditions of members of koperasi Wanita, and the potential of Koperasi Wanita the future. The study was conducted at the Koperasi Wanita "Srikandi" in Sidokerto, Buduran, Sidoarjo. This research is qualitative and uses data collection techniques through interviews, observation and documentation. This study uses a qualitative approach because this study intends to find, understand, explain and obtain a picture of the role of the Koperasi Wanita "Srikandi" in increasing the incomes of members, especially community mothers around the Koperasi Wanita in Sidokerto, Buduran, Sidoarjo. The determination of informants is based on design samples to be able to represent all members of the Koperasi Wanita "Srikandi", then determined 15 respondents, namely 10 respondents from members and 5 respondents from the management of the Koperasi Wanita "Srikandi" After that an analysis of income through the average amount of income per year during the last five years, starting from 2013 to 2018. From the results of the study showed that the Koperasi Wanita "Srikandi" has a positive role in increasing the income of members and its existence benefits the members. Women apparently have an active role in the economy, an optimal potential empowerment towards productivity, so that they are able to achieve economic prosperity through cooperative activities. Women's participation through cooperatives is proven to have helped the family economy. This can be seen from the analysis of respondents' income and statements from respondents directly. From the statement given by each respondent that the respondents felt that the existence of the Koperasi Wanita Srikandi especially the Savings and Loans Unit and special training for members played an important role in business capital to keep going and even more advanced businesses. Although there are many financial institutions in the village of Sidokerto, Buduran, Sidoarjo, the respondents feel it is still more profitable to be a customer and a member of the Koperasi Wanita "Srikandi". In addition respondents also felt the benefits of having business units managed by the Koperasi Wanita "Srikandi" because they were able to meet the needs of members so that the Koperasi Wanita "Srikandi" gained the trust of the members. The trust of members is certainly responded by the Koperasi Wanita "Srikandi" by doing the best service so that members feel comfortable and prosperous.
\end{abstract}

Keywords: empowerment, economy, welfare, potential, Koperasi Wanita 


\section{INTRODUCTION}

Spread of cooperatives in cities and districts in Indonesia aims to be able to embrace all citizens throughout the archipelago. Sidoarjo as one of the regencies in East Java Province has economic potential that needs to be taken into account. Cooperative is an organization that is proclaimed and supported by the government with this organization is able to improve the welfare of the community through increasing per capita income for both members and non-members. The existence of cooperatives in Sidoarjo in the development and development of the people's economy is expected to be able to improve the economic welfare of the community by increasing income.

Koperasi Wanita (KopWan) is a Cooperative with the majority of management and members as women or mothers from the community around the Koperasi Wanita. This cooperative is a Government Program to empower mothers in the surrounding area. The Koperasi Wanita "Srikandi" was established in 2010. Currently the "Srikandi" Cooperative has around 53 members, the number of management is 5. Koperasi Wanita "Heroine" has four business units from the SHU during the last years has increased constantly and so spacious work area coverage Koperasi Wanita "Heroine". This shows that the existence of the Koperasi Wanita "Srikandi" provides a role in the life of the community of Sidokerto, Buduran, as seen from the business units that are able to continue to grow and produce and the number of members has not decreased. Seeing so many other Koperasi Wanita that are only able to manage only a few businesses and SHU produced small, the Koperasi Wanita "Srikandi" which has various types of businesses that produce SHU increases annually should be considered in its role to members of course in the provision of loans so that members can develop businesses and can increase his income.

\section{PROBLEM FORMULATION}

1. How is the Role of Koperasi Wanita "Srikandi" in Efforts to Empower Women in Sidokerto, Buduran, Sidoarjo?

2. What is the Welfare Level of the Koperasi Wanita "Srikandi" Member in Sidokerto, Buduran, Sidoarjo?

\section{PHENOMENON OF KOPERASI WANITA}

According to Bambang Rustanto, Koperasi Wanita is an association / organization that originates from the community, especially women and is formed on the awareness of the community itself, the needs or problems they face. In this forum they share information, provide mutual support both materially and emotionally, as well as a sense of fate and continuity so they have concern. Simply put, cooperatives can be a solution to the problem of poverty at least in East Java. After Law No. 25 of 1992 concerning cooperatives is a business entity consisting of individuals or cooperative legal entities, based on their activities based on cooperative principles as well as the people's economic movement. ${ }^{1}$ the working area of the Koperasi Wanita "Srikandi" can be expanded throughout the Sidoarjo and surrounding areas. As the needs of the community develop, the Koperasi Wanita is also directly proportional to the development that makes the Koperasi-koperasi Wanita an all-round organization such as a shop business, a service business, a savings and loan business, a nominating business, a catering business, a livestock business and so on.

\section{Cooperatives in Microeconomics and Macroeconomics}

In the micro dimension, cooperatives have the same obligations and rights as other economic actors. In the macro dimension, cooperatives are ideologies or ideologies that must become role models for national economic actors.

\section{Cooperatives as a Means of National Development Policy}

\footnotetext{
${ }^{1}$ Arifin Sitio, Cooperative: Theory and Practice, Jakarta: Erlangga, 2001, p. 18
} 
If viewed from the perspective of the government that supports the development of cooperatives it is not considered as the final target in the context of implementing national development policies. There are 3 important differences regarding cooperatives as a means of government, as autonomous self-help facilities of members and cooperatives controlled by the State such as cooperatives as government facilities or tools, cooperatives are considered by the government as self-supporting tools, and cooperatives controlled by the state.

\section{Productivity Towards Independence}

Women's participation in improving the economy of the community women's has contributed to their community, aside from being a housewife, they also try to care for the community where they live and live.

Empowerment is the context of the effort for a society so that it is empowered, has an awareness that the presence of individuals in it is to have potential and ability more than perceived. Empowerment is a condition or condition that supports the strength or ability of the community so that they can actualize their true identity, desire and dignity to survive and develop themselves independently. The concept of empowerment carried out by a group of women is quite unique and innovative, because even though it is underestimated, they never give up to empower themselves. ${ }^{2}$

Departing from this side, it is not excessive if the encouragement for women to dare to reveal their true identity and try as much as possible to pump up their potential and express the existence of their identity. The government did not stay silent, many training courses and seminars were opened to hone the skills of women in managing and managing their cooperatives.

\section{Improvement of Community Living Standards The}

Context of empowerment always refers to weak community groups, namely the people who are in caste low due to being a victim of dynamics development. ${ }^{3}$ The role of women being important presence in empowerment this, because it is essentially empowering society is an effort to improve the dignity and level of society in the present condition unable to let go yourself from the trap of poverty and trap backwardness. In terms of terminology, if we dissect the word empowerment is an effort to enable and be independent Public. ${ }^{4}$

When viewed in terms of humanitarian responsibility both individually and socially even religiously, the existence of women in the midst of society must present its own dynamicconstructive color as well as men, in whatever sense the role of women in the family and community. In its contextualization, empowerment (empowerment) is a concept that was born as part of the natural development of people's minds and culture. Empowerment is not in the context of dominating others, but placing empowerment as a skill to increaseself-reliance and internal strength. ${ }^{5}$

Islam as a religion rahmatan lil alamin, is a religion that takes sides women. Islam does not deter women to enter various professions accordingly with his expertise, such as being a teacher / lecturer, doctor, businessman, minister, judge and others, even if he is able to become prime minister or head of state, as long as he is in his duty to pay attention to the laws and regulations stipulated by Islam. Even from the other side, the truth of Islam is entrusting the great potential of women in building society.

The role of women in society is essentially to help families achieve prosperity. In other words, the role of women through cooperative empowerment in essence is to help husband in supporting the family on the basis of the spirit of mutual help to help in kind.

\section{RESEARCH METHODS}

\footnotetext{
${ }^{2}$ Masykuri Bakri, Community Empowerment; RRA and PRA approaches, (Surabaya: Visipress Media, 2011), p. 1718.

${ }^{3}$ Ibid., H. 47

${ }^{4}$ Ibid., H. 47

${ }^{5}$ KARSA Journal, Vol. 19. No.2. In 2011, p.139.
} 
This study uses a qualitative approach because this research intends to find, understand, explain and obtain a picture of the role of the Koperasi Wanita "Srikandi" in increasing the income of members of the Buduran, Sidoarjo so that a complete picture is obtained from the analysis of the role of the Koperasi Wanita in economic development rural community. By focusing on the process and search for meaning behind the phenomena that arise in research, aiming that the information being studied is more comprehensive and in-depth. The research was carried out in Sidokerto, Buduran, Sidoarjo with the practical reason that the research was carried out for efficiency in terms of time, cost, and energy so that the results could be maximized.

In this study, the data obtained came from two sources, namely:

1. Primary data, data obtained by researchers directly from the source or data obtained directly from the field directly. The sources of data directly from research are:

a. Key informants which included 10 Members of the Koperasi Wanita "Srikandi" in Sidokerto, Buduran, Sidoarjo.

b. Supporting informants included Koperasi Wanita "Srikandi" Management in Sidokerto, Buduran, Sidoarjo, as many as 5 womans in Koperasi Wanita "Srikandi", consisting of: Mrs. Satini, Deputy Chairperson: Mrs. Mamik, Secretary: Mrs. Samiaji, Treasurer 1: Mrs. Erni, Treasurer 2: Mrs. Sutinah.

2. Secondary data, is data obtained indirectly from the source of this data in the form of documents, reports, articles that are related to the problem under study. In this case the secondary data was obtained from the data book of the Koperasi Wanita "Srikandi" of Sidokerto, Buduran, Sidoarjo. Data collection techniques used in this study were observation, interviews and documentation.

In this study the instruments used included: Interview guidelines, field notes and the researchers themselves. In this study the data obtained will be analyzed and interpreted, where the data used is a qualitative analysis model.

\section{RESULTS AND DISCUSSION}

\section{Overview of the Koperasi Wanita "Srikandi"}

Koperasi Wanita is located on Jalan Sono indah Rt.01 Rw.03, Sidokerto, Buduran, Sidoarjo. This cooperative was established on March 11, 2003 which has the special characteristics of all the management and members consisting of housewives. Of course, because the managers are women, most of the production of their activities is related to the needs of mothers. In 2010-2011, the Koperasi Wanita "Srikandi" had around 48 members with an outstanding financial circulation of Rp. 325.089.500.00. Then in 2013-2018, the number of members of the Koperasi Wanita "Srikandi" only increased by 5 people to 53 people with an outstanding financial circulation of Rp. 368.076.500.00.

From the results of the interview with Mrs. Satini the Koperasi Wanita "Srikandi" as follows: The Koperasi Wanita "Srikandi" does not have a manager and therefore the management divides the task of directing business units according to their respective expertise. So all the issues raised in the business units directly handled by the board while the form of coaching the form of guidance in administration, finance and ways to manage the business so that each unit is able to finance its own activities (Interviews in December 5, 2019 at 09.00 am at the office of the board).

\section{The Role Koperasi Wanita "Srikandi"}

Role of the Koperasi Wanita "Srikandi", among others, is through:

Members in the Koperasi Wanita "Srikandi" are still passive members where members pay only basic savings (Interview on December 5, 2019 at 09.00 WIB at the office of the management). According to Law Number 25 of 1992 concerning the subject matter of Indonesian Cooperatives chapter VI article 21 organizational equipment consists of: 1. Member meeting 2. Management 3. Examining and supervisory bodies From the results of interviews with Mrs. Satini as Leader of the Koperasi Wanita "Srikandi" follows: Koperasi Wanita "Srikandi" does not have 
a manager and therefore the management divides the task of building directly to business units in accordance with their respective expertise. So all the problems that occur in business units are directly handled by the management while the form of guidance is in the form of administrative, financial and ways to manage the business so that each unit can finance its own activities (Interview 5 December 2019 at 09.00 WIB at the office of the management).

1. Business Unit

\begin{tabular}{|c|c|c|c|}
\hline No & Business Unit & Quantity. Employees & Information \\
\hline 1 & Self-Service & 15 & Independent \\
\hline 2 & Water Oxygen (AO) & 10 & Independent \\
\hline 3 & Car Rental & 13 & Independent \\
\hline 4 & Saving Loans & 5 & Independent \\
\hline
\end{tabular}

Source: Archives of the Koperasi Wanita "Srikandi"

From the table above the Self-Service Unit has the most Employees. This is because there are two self-service shifts which are managed by the Koperasi Wanita "Srikandi", which is the morning shift with 7 employees and 8 employees in the afternoon so that the total self-service employees are 15 employees with alternating work time schedules due to open starting at 08.00 20.00 Unlike other units that are open. After this there will be an explanation of the units owned by the Koperasi Wanita "Srikandi".

2. Special Training for Members in the form of:

a. Sewing training

b. Catering training

Microsoft Office (Computer) training

3. Regular coaching every month and every year organized by the management through Field Officers.

\section{ANALYSIS OF MEMBER INCOME}

One of the business units developed by the Koperasi Wanita "Srikandi" is a Savings and Loan Unit, although in Sidokerto along the road approximately $2 \mathrm{~km}$ there are many credit financial institutions both government and non-government institutions. With the proliferation of credit institutions the management of the Koperasi Wanita "Srikandi" is taking steps so that the community will put their trust in the Savings and Loan Unit. The steps taken by the management turned out to be right, it can be seen that the SHU from the Savings and Loans unit can be said to be quite large, even the Savings and Loans unit is a mainstay business unit because every year gets the biggest SHU from all the units in the Koperasi Wanita "Srikandi". The Board hopes that by taking this step, it will be able to meet the needs of the community, especially members and be able to increase the welfare of members and the community through increased income. Services provided to customers such as smiling greetings, comfortable waiting rooms, easy requirements make customers trust. In accordance with the objectives of the study, the researchers analyzed the increase in income of members of the Koperasi Wanita "Srikandi" by observing the average income per year for the last five years starting from 2013 to 2018. The average net income of respondents experienced an increase starting from 2013 to 2018, although not an increase continues. Bu Anis Grocery Store Respondents Sidokerto, Buduran are respondents who continue to experience annual increases with an average increase of $4 \%$ per year.

\section{BENEFITS OF THE ROLE OF THE KOPERASI WANITA "SRIKANDI" OBTAINED BY MEMBERS}

In its business the Koperasi Wanita "Srikandi" has four business units in which each unit contributes to SHU annually. The four business units include the Savings and Loan Unit, Unit Supermarkets, Oxygen Water Unit (AO) and transportation rental units. The following is the influence of these units on member income. Every customer wants conduct financial transactions 
in accordance with their needs are required to meet obligations already set it. Savings and Loans Unit felt very useful presence for members and the community in the midst of other financial institutions deemed to have requirements not as easy as the Koperasi Wanita "Srikandi Savings and Loan unit. With good service a joint responsibility system that can leverage members and relatively little interest customers both members and the community feel comfortable and trust to be customers. Results from all the informant statements given prove that the Self-service unit provided benefits for members and the community to meet the various needs of the family. Starting from toiletries, kitchenware, snacks and so on are available at supermarkets at relative prices affordable so that members and the public do not need to go to the city and rent a special stand for selling the products of the members' businesses making it easier for members to market the product his effort. Drinking water oxygen (AO) is very much needed by the community so the establishment of the Koperasi Wanita "Srikandi" (AO) oxygen drinking water unit was very useful for public health. Likewise with the very rental transportation unit useful for members and the community because of the affordable prices and complete facilities. For the role of the Koperasi Wanita "Srikandi" in the form of special training in Above is very influential to increase member skills and is very useful for the provision of business of course to increase the income of members, Thus members feel increasingly comfortable going to be a member of the Koperasi Wanita "Srikandi".

Coaching members are held every month and every year through member meetings Monthly (RAB) and Annual Member Meetings (RAT), which contain business coaching for members as well provide the latest information about the Koperasi Wanita "Srikandi" is also very useful for added cohesiveness to further enhance member participation.

\section{CONCLUSIONS}

1. Based on the research that I did at the Koperasi Wanita "Srikandi", the most influential role in the members' income was in several parts of the business units and HR development program members, namely:

The role of the Koperasi Wanita "Srikandi" through the Savings and Loan Unit was very influential in income of members, until the members feel at home for many years as customers. Business coaching is held every month and every year through the RAB and RAT at the home of each group leader, as well as good employee services and relatively lower interest rates than other financial institutions.

3. The role of the Koperasi Wanita "Srikandi" through the Self-Service Unit members also feel the benefits in increasing income. In the Supermarkets Unit can also act as a distributor for members, so members can entrust their light business products such as cakes and snacks to be marketed at the supermarket and for members who want to rent a stand where the supermarket stands. heavy like clothes and headscarves, so members can more easily market their products through the Koperasi Wanita Srikandi. So that the welfare of the community, especially members of the Koperasi Wanita "Srikandi" continues to improve and the economy becomes better. 


\section{BIBLIOGRAPHY}

Central Statistics Agency 2010-2014, East Java in 2014 Numbers. Surabaya; BPS

Statistics Indonesia 2010-2014, Pasuruan in Figures 2010. Pasuruan; BPS

Boediono, Dr. 1982. Macroeconomics. Yogyakarta; BPFE

Boediono, Dr. 1982. Microeconomics. Yogyakarta; BPFE

Djokohadikusumo, Sumitro. 1994. Development of Economic Thought Basic Economic Growth and Development Economics. Jakarta ; PT Pustaka LP3ES

Hanel, Alfred. 1989. Cooperative Organizations: Principles for Thinking about Cooperative Organizations and Development Policy in Developing Countries. Bandung: Space.

Hasibuan, Nurimansyah. 1987. The History of Ekono's Thought. Jakarta: UT. Ministry of Education and Culture

Fadilah, Yusuf. 2011. The Existence of Women's Cooperatives in Indonesiacooperatives-wanitain Indonesia, https://yusuffadillah.wordpress.com/2011/12/21/existence-/ on Access 12 January 2020. 